\title{
The influence of the complex deformation on the microstructure and mechanical properties of the model Al-Li alloys
}

\author{
Wpływ złożonego sposobu odkształcenia \\ na mikrostrukturę i właściwości mechaniczne modelowych stopów Al-Li
}

\author{
MILENA KORALNIK \\ BOGUSKAWA ADAMCZYK-CIEŚLAK \\ JAROSŁAW MIZERA *
}

\author{
DOI: 10.17814/mechanik.2016.5-6.60 \\ Międzynarodowa Konferencja IMT 2016
}

\begin{abstract}
The present study demonstrate the effect of the combined deformation (hydrostatic extrusion and rolling) on microstructure and mechanical properties of model AlLi alloys. It has been shown the anisotropy of material structure and properties. Additionally it has been demonstrated increase of yield strength at the result of the plastic deformation.
\end{abstract}

KEYWORDS: Al-Li alloy, hydrostatic extrusion, microstructure and properties

W pracy przedstawiono wpływ łączonego odkształcenia wyciskania hydrostatycznego i walcowania na zimno na mikrostrukturę i właściwości modelowych stopów Al-Li. Badania wykazały obecność anizotropii struktury materiału i właściwości. Ponadto przedstawiono wzrost właściwości wytrzymałościowych w wyniku odkształcenia plastycznego.

SŁOWA KLUCZOWE: stopy Al-Li, wyciskanie hydrostatyczne, mikrostruktura i właściwości

Al-Li alloys are extensively used in many areas of industry, especially the aircraft, because of low density and strong ability to hardening. They are suitable materials for basic investigation, where are interested in the interaction be-

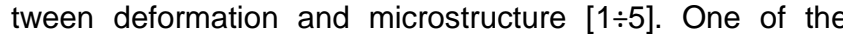
method of strengthening is plastic deformation or heat treatment. The aim of the present study was analyzed of complex deformation influence on the microstructure and mechanical properties of the model Al-Li alloys.

\section{Materials and methods}

The materials used in the investigations were two model aluminum - lithium alloys of a chemical composition (wt. \%) given in Tab. I. The second alloy was subjected the additional heat treatment (heat treated at $823 \mathrm{~K}$ for $10 \mathrm{~h}$ and subsequently water-quenched to room temperature and than aging at $473 \mathrm{~K}$ for $2 \mathrm{~h}-\mathrm{T} 6$ treatment).

In the first step the alloys were deformed by hydrostatic extrusion (HE) method in the range of the true strain $\varepsilon=2.4$. The second step the bars were cold rolled (CR) in accordance with direction of the extrusion process. Finally the samples, as a result of plastic deformation had about $4 \mathrm{~mm}$ width and $1 \mathrm{~mm}$ of thickness.

The structures of the deformed samples was examined on transverse and longitudinal sections to the extrusion direction. Microstructures were examined by light microsco-

\footnotetext{
* Mgr inż. Milena Koralnik (milena.koralnik@inmat.pw.edu.pl), dr inż. Bogusława Adamczyk-Cieślak, prof. nadzw. dr hab. inż. Jarosław Mizera - Wydział Inżynierii Materiałowej, Politechnika Warszawska
}

py with polarized light beam (LM) and transmission electron microscope (TEM) at an accelerating voltage of $120 \mathrm{keV}$. The obtained images (perpendicular and parallel sections) were analyzed quantitatively by the stereological methods using special software for image analysis [6]. The grain sizes were determined for more than 400 randomly selected grains.

TABLE I. The chemical composition of analyzed alloys

\begin{tabular}{|c|c|c|c|c|c|}
\hline \multirow{2}{*}{$\begin{array}{c}\text { Mark } \\
\text { of alloys }\end{array}$} & \multirow{2}{*}{ Alloy } & \multicolumn{4}{|c|}{$\begin{array}{c}\text { Weight participation } \\
\text { of elements, \% }\end{array}$} \\
\cline { 2 - 5 } & & $\mathrm{Li}$ & $\mathrm{Zr}$ & $\mathrm{Cu}$ & $\mathrm{Al}$ \\
\hline I & $\mathrm{Al}-2.2 \mathrm{Li}-0.1 \mathrm{Zr}$ & 2.2 & 0.1 & - & \multirow{2}{*}{ bal. } \\
\hline II & $\mathrm{Al}-2.2 \mathrm{Li}-1.2 \mathrm{Cu}-0.1 \mathrm{Zr}$ & 2.2 & 0.1 & 1.2 \\
\hline III & $\mathrm{Al}-2.2 \mathrm{Li}-1.2 \mathrm{Cu}-0.1 \mathrm{Zr}(\mathrm{T} 6)$ & 2.2 & 0.1 & 1.2 & \\
\hline
\end{tabular}

In order to determine mechanical properties tests such as microhardness measurements (HV 0.2) and compression test were performed. A microhardness measurements were carried out for the samples at perpendicular and parallel sections as well. Presented values are average from 30 measurements each. From the compression test were appointed the yield strength value only. Because of small dimensions of samples yield strength were define by compression test. The obtained results well correspond to the values presented on the work [7]. During compression tests the speed of the deformation was almost equal $\varepsilon^{\prime} \approx 1.5 \times 10^{-2}[1 / \mathrm{s}]$.

\section{Results and discussion}

- Microstructure. The Fig. $1 \div 3$ shows compilation of microstructures images of investigated alloys and designated value of average grain size $\left(d_{\mathrm{av}}\right)$. Observations carried out with polarized LM demonstrated strong deformation. It is observed in the form of elongated grains at the longitudinal section of materials. At the transverse section the grains have the irregular shape. It can be seen many disorientation bands. Such a structure witness to the trend to concentrate local plastic deformations. Observations obtained during investigation are similar to another works $[8,9]$. Presented results demonstrate the presence of the band structure. The TEM observations expose strong defected structure with many dislocations. On the basis of stereological analysis equivalent diameter was identified. Base on the results of average grain size it could be concluded the differences of microstructure between the alloys and effect of heat treatment. It was noticed that was not significant changes in grain size as a result of additional CR process at the sample I according to the results presented at work [8] after HE only. 


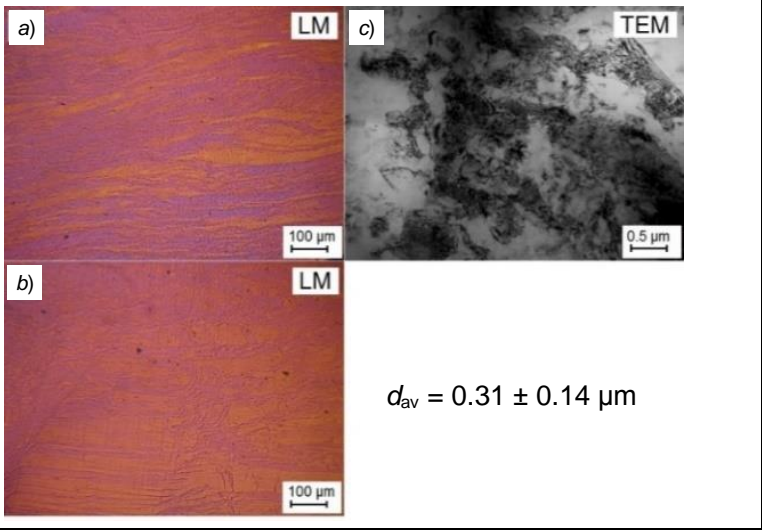

Fig. 1. Microstructures of the Al-2,2Li-0,1Zr alloy after combinated methods of deformation $(\mathrm{HE}+\mathrm{CR})$ : a) cross section, $b-c)$ parallel section to the rolling direction

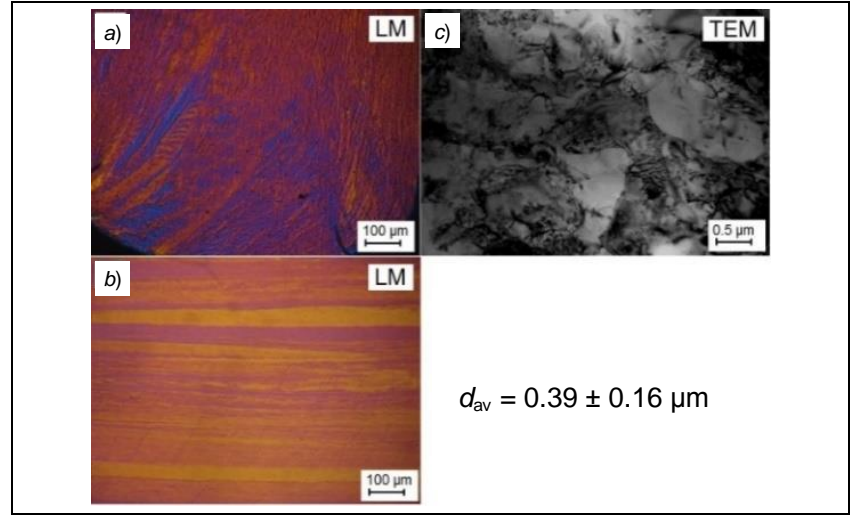

Fig. 2. Microstructures of the Al-2,2Li-1,2Cu-0,1Zr alloy after combinated methods of deformation $(\mathrm{HE}+\mathrm{CR})$ : a) cross section, $b-c)$ parallel section to the rolling direction

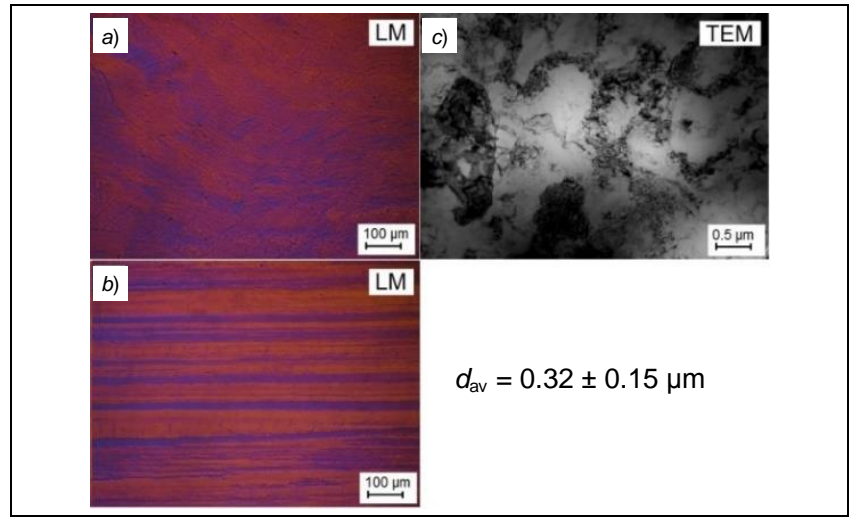

Fig. 3. Microstructures of the Al-2,2Li-1,2Cu-0,1Zr (T6) alloy after combinated methods of deformation $(\mathrm{HE}+\mathrm{CR})$ : a) cross section, $b-c)$ parallel section to the rolling direction

Based on results of the microhardness it could be concluded the anisotropy of the mechanical properties in investigated alloys. This could be due to the tendency to locate the plastic deformation in the form of deformation bands $[9,10]$. This process is strong related with the kind of crystallographic texture [11]. Texture is formed as a result of deformation processes. The obtained values of microhardness for materials after $\mathrm{HE}$ and $\mathrm{CR}$ are similar to the values after only HE [8].

- Mechanical properties. The results obtained by microhardness were shown in Tab. II. The compression tests were used for estimated yield strength of investigated samples. The results shows that the yield strength for alloy I is about $470 \mathrm{MPa}$, while for sample with copper addition about $410 \mathrm{MPa}$.
TABLE II. The microhardness measurement results for the tested Al-Li alloys

\begin{tabular}{|c|c|c|c|}
\hline \multirow{2}{*}{ Mark of alloys } & \multicolumn{3}{|c|}{ Microhardness [HV 0.2] } \\
\cline { 2 - 4 } & \multicolumn{3}{|c|}{$\mathrm{HE}+\mathrm{CR}$} \\
\cline { 2 - 4 } & $\begin{array}{c}\text { transverse } \\
\text { section }\end{array}$ & $\begin{array}{c}\text { parallel } \\
\text { section }\end{array}$ & $\begin{array}{c}\text { parallel } \\
\text { section }\end{array}$ \\
\hline I & 158 & 114 & 118 \\
\hline II & 116 & 136 & 137 \\
\hline III & 171 & 152 & - \\
\hline
\end{tabular}

Heat treatment of alloy II increases the value of yield strength up to $450 \mathrm{MPa}$. The obtained values clearly demonstrate the increase of yield strength after complex deformation compare to the sample after only CR process yield strength about $280 \mathrm{MPa}$ for $\mathrm{Al}-\mathrm{Li}-\mathrm{Zr}$ and $320 \mathrm{MPa}$ for $\mathrm{Al}-\mathrm{Li}-\mathrm{Cu}-\mathrm{Zr}$ alloy [9]. Different values are a consequence of changes in microstructure (grains size) of the samples. In accordance with the Hall-Patch relationship for sample I, the value of yield strength is the higher than the second alloy due to smaller average grain size.

\section{Conclusions}

The aim of the present research was to analyze the influence of complex deformation on the microstructure and mechanical properties of $\mathrm{Al}-\mathrm{Li}-\mathrm{Zr}$ and $\mathrm{Al}-\mathrm{Li}-\mathrm{Cu}-\mathrm{Zr}$ alloys. There was demonstrated, that additional deformation process (CR after HE) had no significant influence on the microstructure of the materials. The results of stereological analysis and the microhardness measurements showed similar values using various methods of deformation. However, the strong anisotropy of microhardness was demonstrated. The values of yield strength are higher for alloys after complex deformation compared to the samples after single deformation process. The results are confirmed by grain size analysis and microscopic observation exhibiting microstructure changes and high density of dislocation.

\section{LITERATURE}

1. Sanders Jr T.H., Strake Jr E.A. „Aluminum-Lithium Alloys”. New York: TMS-AIME, 1981.

2. Baker C., Gregson P.J., Harris S.J., Peel C.J. „AluminumLithium Alloys". London: The Institute of Metals, 1986.

3. Das S.K., Yin W. „Aluminum Alloys for Transportation, packaging, Aerospace and Rother Applications". The Minerals, Metals and Materials Society, Warrendale Pennsylvania, 2007.

4. Davis J.R. ASM „Specialty Handbook, Aluminum and Aluminum Alloys". USA, AMS International, 1993

5. Shen Y.Z., Oh K.H., Lee D.N. „Serrated behavior in $2090 \mathrm{Al}-\mathrm{Li}$ alloy influenced by texture and microstructure". Mater. Sci. Eng:

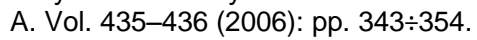

6. Wejrzanowski T., Spychalski W.L., Rożniatowski K., Kurzydłowski K.J., „Image based analysis of complex microstructures of engineering materials". Int. J. Appl. Math. Comp. Vol. 18, No. 1

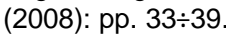

7. Sinay G., Major G., Kiss E., Bitka T. Tatrzański K., Primke K. „Aluminium Poradnik". Warszawa: Wydawnictwo NaukowoTechniczne, 1967.

8. Adamczyk-Cieślak B. „Analiza stabilności termicznej stopów aluminium poddanych dużemu odkształceniu plastycznemu". Warszawa: PW Wydział Inżynierii Materiałowej, 2009.

9. Mizera J., Kurzydłowski K.J. „On the anisotropy of the PortevinLe Chatelier plastic instabilitiers in Al-Li-Cu-Zr alloy". Scripta Mater. Vol. 45 (2001): pp. 801 $\div 806$.

10. Diego N., Rio J., Romero R., Somoza A. „A position study on the microstructural evolution of Al-Li based alloys in the early stages of plastic deformation". Scripta. Mater. Vol. 37 (1997): pp. $1367 \div 1371$.

11. Vasudevan A.K., Przystupa M.A., Fricke Jr W.G. „Effect of composition on crystallographic texture of hot-rolled Al-Li binary al-

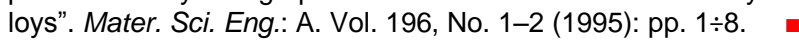

